\title{
Production and standing stock of copepod nauplii, food items for larvae of the walleye pollock Theragra chalcogramma in the southeastern Bering Sea
}

\author{
M. J. Dagg ${ }^{1}$, M. E. Clarke ${ }^{2}$, T. Nishiyama ${ }^{3}$ and S. L. Smith ${ }^{4}$ \\ ${ }^{1}$ Louisiana Universities Marine Consortium, Star Route, Box 541, Chauvin, Louisiana 70344, USA \\ ${ }^{2}$ Scripps Institution of Oceanography, A-008, University of California at San Diego, La Jolla, California 92093, USA \\ ${ }^{3}$ Institute of Marine Science, University of Alaska, Fairbanks, Alaska 99701, USA \\ 4 Oceanographic Sciences Division, Brookhaven National Laboratory, Upton, New York 11973, USA
}

\begin{abstract}
In late May 1981, during a $48 \mathrm{~h}$ study in the southeast Bering Sea, each Pseudocalanus spp. female produced an average of 5.1 nauplii $\mathrm{d}^{-1}$, resulting in a production of 25,757 nauplii $\mathrm{m}^{-2} \mathrm{~d}^{-1}$ by the Pseudocalanus spp. population. Similar calculations showed that the only other abundant copepod female at this station, Oithona spp., produced 1,337 nauplii $\mathrm{m}^{-2} \mathrm{~d}^{-1}$. From these rates, it is calculated that a standing stock of 721,034 nauplii $\mathrm{m}^{-2}$ would result if there were no mortality. However, lower temperatures and lower concentrations of females were found prior to our study and a more realistic estimate of the potential stock is 495,328 nauplii $\mathrm{m}^{-2}$. The average observed stock of nauplii was $463,173 \mathrm{~m}^{-2}$, suggesting a mortality rate between 7 and $36 \%$ of the daily production with values in the lower part of this range being more probable. Pollock larvae, found at an average concentration of $6.3 \mathrm{~m}^{-2}$, ingested an average of 115 nauplii $\mathrm{m}^{-2} \mathrm{~d}^{-1}$ and therefore ingested only a small fraction of the daily naupliar production. It is concluded that pollock larvae are insignificant as predators on copepod nauplii, and that overall naupliar mortality is low during the springtime in this area.
\end{abstract}

\section{INTRODUCTION}

In many species of fish, larval survival and growth are related to food concentration. This has been demonstrated in laboratory studies, for example with haddock Melanogrammus aeglefinus (Laurence, 1974); bay anchovy Anchoa mitchilli (Saksena and Houde, 1972); scaled sardine Harengula pensacola (Saksena and Houde, 1972); sea bream Archosargus rhomboidalis (Houde, 1978); lined sole Achirus lineatus (Houde, 1978); winter flounder Pseudopleuronectes americanus (Laurence, 1977); and anchovy Engraulis mordax (Lasker et al., 1970), as well as in field studies (Lasker, 1975, 1978). Feeding success during the period immediately following hatching and yolk-sac absorption is considered critical for survival in many fish species (see review by May, 1974) and an increased understanding of the in situ relations between production and abundance of food items and feeding rates of larvae fish is an important goal in fisheries oceanography.

The walleye pollock Theragra chalcogramma is estimated to represent 20 to $50 \%$ of the total standing stock of the demersal fish in the Bering Sea (Smith, 1981) and is an important commercial fish; as much as $75 \%$ of the total annual weight of fisheries products removed from the Bering Sea is pollock. Newly hatched, yolk-sac larvae are about 3.5 to $4.0 \mathrm{~mm}$ long. There is evidence that this yolk-sac stage (to about 5.0 to $5.5 \mathrm{~mm}$ ) lasts 15 to $20 \mathrm{~d}$ (Hamai et al., 1974). After yolk-sac absorption, growth rate appears to be about $0.35 \mathrm{~mm} \mathrm{~d}^{-1}$ during the early larval phase, to $9.5 \mathrm{~mm}$ (Hayashi et al., 1968; Walline, 1980; Nishiyama, unpubl.). Thus for a pollock larvae to grow from 3.5 to $9.5 \mathrm{~mm}$ requires approximately $1 \mathrm{mo}$. During the period between hatching and the end of the early larval stage, copepod nauplii comprise $>95 \%$ of the items in the larval diet (Kamba, 1977; Clarke, 1978; 
Nishiyama and Hirano, 1984). Only when pollock larvae grow to $>10.5 \mathrm{~mm}$ do other diet items, primarily copepodid stages and adults of small copepod species, become significant. Growth and survival of first feeding pollock larvae are therefore dependent on the availability of copepod nauplii.

In the southeastern Bering Sea pollock spawning occurs from Feb to Jun, with a peak in early May (Smith, 1981). One of the major spawning sites in the Bering Sea is the middle shelf region, between the 50 and $100 \mathrm{~m}$ isobaths, to the north and northwest of Unimak Island (Fig. 1). In this region high concentrations of pollock eggs and larvae occur (Waldron, 1981); it was chosen as a good location for a detailed examination of in situ interactions between newly hatched pollock larvae and their food items, copepod nauplii.

\section{METHODS AND MATERIALS}

Prior to our $48 \mathrm{~h}$ study in late May, 1981, the area between $55^{\circ} \mathrm{N}$ and $58^{\circ} \mathrm{N}$, and $162^{\circ} \mathrm{W}$ and $166^{\circ} \mathrm{W}$ (Fig. 1) was surveyed for pollock eggs and larvae in

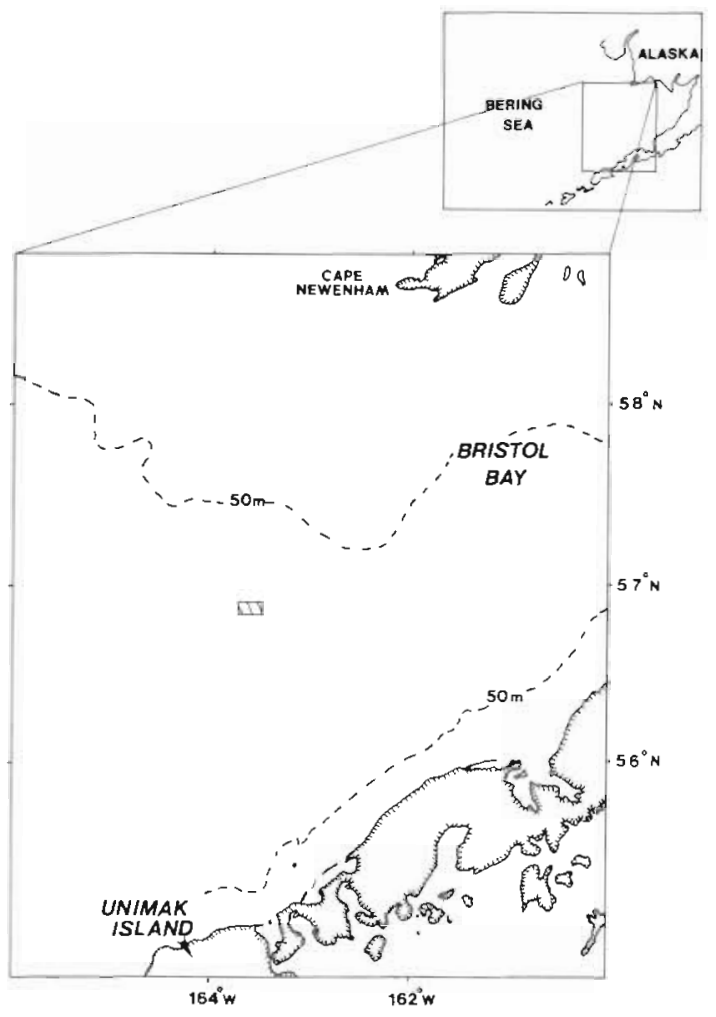

Fig. 1. Area sampled during $48 \mathrm{~h}$ study is enclosed by small cross-hatched area. Station locations are: Sta. 1: $56^{\circ} 50.8^{\prime} \mathrm{N}$, $163^{\circ} 34.1^{\prime} W_{;} \quad$ Sta. 2; $56^{\circ} 50.8^{\prime} \mathrm{N}, 163^{\circ} 31.2^{\prime} \mathrm{W}^{\prime}$ Sta. 3: $56^{\circ} 51.5^{\prime} \mathrm{N}, \quad 163^{\circ} 31.6^{\prime} \mathrm{W} ;$ Sta. $4: 56^{\circ} 51.2^{\prime} \mathrm{N}, 163^{\circ} 37.6^{\prime} \mathrm{W}_{\text {; }}$ Sta. 5: $\quad 56^{\circ} 51.4^{\prime} \mathrm{N}, \quad 163^{\circ} 33.4^{\prime} \mathrm{W}_{i} \quad$ Sta. $6: \quad 56^{\circ} 49.7^{\prime} \mathrm{N}$, $163^{\circ} 35.1^{\prime} \mathrm{W}_{\mathrm{i}} \quad$ Sta. $7: \quad 56^{\circ} 52.3^{\prime} \mathrm{N}, \quad 163^{\circ} 40.3^{\prime} \mathrm{W}_{\mathrm{i}} \quad$ Sta. 8 : $56^{\circ} 50.4^{\prime} \mathrm{N}, 163^{\circ} 40.3^{\prime} \mathrm{W}$ late Apr and again in mid-May. The specific location of our $48 \mathrm{~h}$ study within this surveyed area was chosen because, in both surveys, the region near $56^{\circ} 50^{\prime} \mathrm{N}$ and $163^{\circ} 35^{\prime} \mathrm{W}$ had the highest densities of pollock eggs and larvae.

An array of sediment traps was deployed at the beginning of our $48 \mathrm{~h}$ study. This array, consisting of a surface spar, sediment traps at 20,40, and $60 \mathrm{~m}$, and a lead weighted plywood plate, served as a drogue. Samples were collected at the drogue location every $6 \mathrm{~h}$. Coordinates of each of the eight stations are given in the caption of Fig. 1. There was little net motion in the drogue during our study; the track was a partial ellipse with a long axis of approximately $5 \mathrm{~km}$, suggesting that the motion was tidally induced (Coachman and Charnell, 1979).

Zooplankton and ichthyoplankton samples were collected with a $1 \mathrm{~m}^{2}$ MOCNESS sampling system (Wiebe et aì., 1976) fitted with $149 \mu \mathrm{m}$ mesh nets for zooplankton, and $505 \mu \mathrm{m}$ mesh nets for ichthyoplankton. Zooplankton samples were collected from 62 to $40 \mathrm{~m}, 40$ to $20 \mathrm{~m}$, and 20 to $0 \mathrm{~m}$; ichthyoplankton samples from 62 to $40 \mathrm{~m}, 40$ to $20 \mathrm{~m}, 20$ to $10 \mathrm{~m}$, and 10 to $0 \mathrm{~m}$. The bottom depth in our study area was 63 to $64 \mathrm{~m}$. All samples were preserved in $5 \%$ formalin in seawater for later enumeration. Pollock larvae were sorted from the samples and the length of each fish was measured with an ocular micrometer (precision $\pm 0.1 \mathrm{~mm}$ ) and categorized into a size group by $0.5 \mathrm{~mm}$ intervals. The gut contents of 15 larvae from each sample were analyzed. All food items were identified as egg, nauplius, or copepodid, and the length and width of each item were measured.

Microzooplankton were sampled with $30 \mathrm{l}$ Niskin bottles; the content of each bottle was drained through a $26 \mu \mathrm{m}$ mesh bag, washed onto a $44 \mu \mathrm{m}$ mesh sieve, back-washed into a glass bottle, and preserved in $5 \%$ formalin in seawater for later enumeration. Microzooplankton were identified as egg, nauplius, or copepodid and the length and width of each item were measured.

Seawater temperatures were measured with a NeilBrown Mark III CTD, which was deployed just prior to each MOCNESS cast. Seawater for chlorophyll analyses was collected in Niskin bottles attached to a rosette sampler and chlorophyll was measured, after extraction with $90 \%$ acetone, according to Strickland and Parsons (1968).

Egg production rates of the dominant copepod, Pseudocalanus spp., were measured on board ship by sorting freshly collected females individually into $50 \mathrm{ml}$ vials containing natural, surface, seawater. Pseudocalanus spp. females typically lose their egg sacs during capture but produce new ones shortly after the onset of an experiment. All vials were examined 
every $12 \mathrm{~h}$ for $8 \mathrm{~d}$. Hatching time was determined by noting the time of egg sac appearance and the time of first nauplius appearance in each vial. The number of nauplii released and the time required for the next egg sac to be produced was recorded. Copepods were then preserved for later determination of the number of eggs in the newly produced egg sac. Food medium (natural seawater) was changed еvery $24 \mathrm{~h}$. All vials

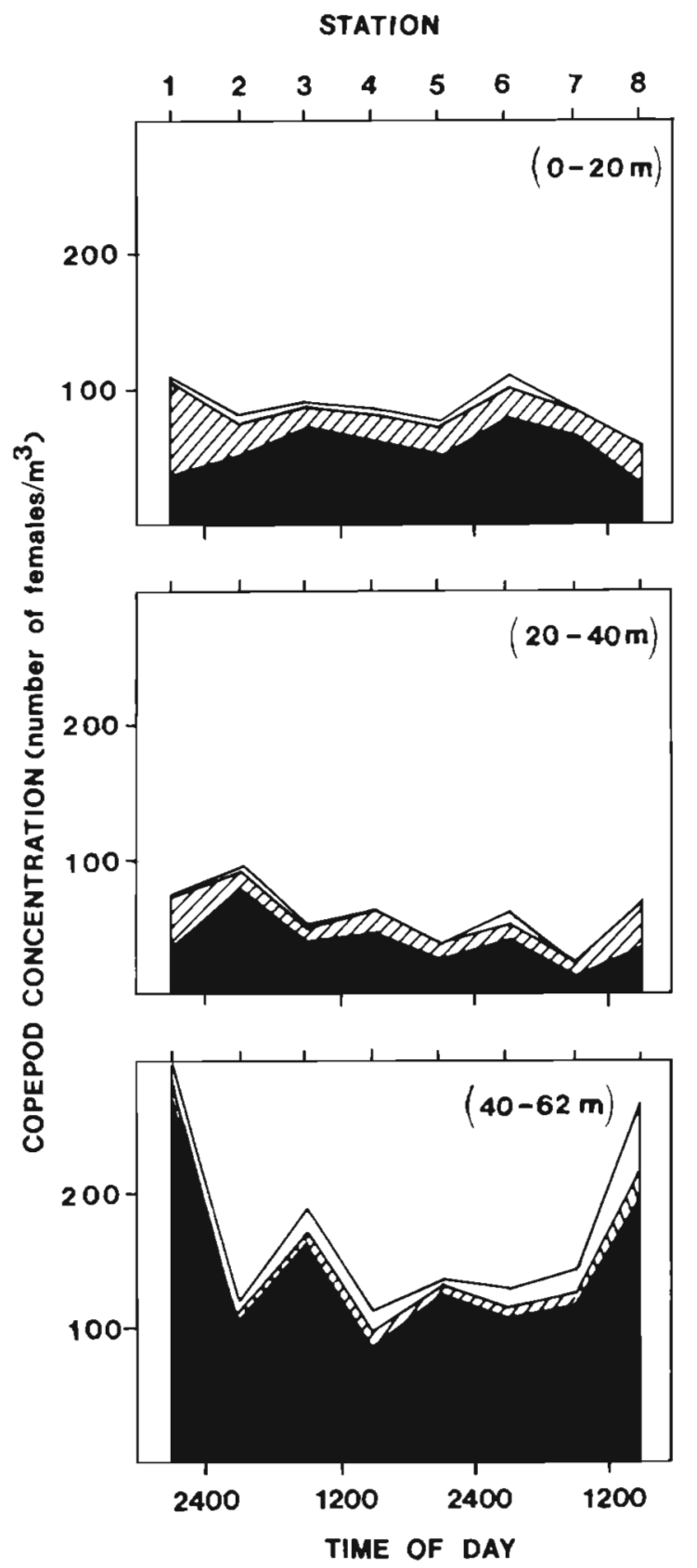

Fig. 2. Concentration of female copepods in upper, middle, and lower depth strata. Black: Pseudocalanus spp.; striped: Oithona spp.; clear: all other females. Other females were primarily Microcalanus sp. $\left(0.0\right.$ to $\left.28.1 \mathrm{~m}^{-3}\right)$ and Calanus marshallae ( 0.0 to $\left.1.2 \mathrm{~m}^{-3}\right)$ were kept in a dark incubator at near-surface temperature on a slowly rotating wheel. Forty-eight females were monitored, 24 collected at the onset of the study, and 24 collected $12 \mathrm{~h}$ later.

\section{RESULTS}

\section{Production of copepod nauplii}

The most abundant adult female copepod found during our $48 \mathrm{~h}$ study was Pseudocalanus spp. (Fig. 2). Females of other copepods were rare (Fig. 2) except for Oithona spp., almost entirely $O$. similis. Pseudocalanus spp. females were most abundant in the bottom depth stratum ( $\overline{\mathrm{x}}=144.4 \mathrm{~m}^{-3}$; Fig. 2) whereas Oithona spp. females were most abundant in the surface stratum $\left(\overline{\mathrm{x}}=25.5 \mathrm{~m}^{-3}\right.$; Fig. 2). There was no apparent vertical migration of either copepod.

In our shipboard experiments, the number of nauplii produced by each Pseudocalanus spp. female varied between 14 and 45 clutch $^{-1}$ (Fig. 3), with an average of 33.0. There was no obvious effect of body size. The

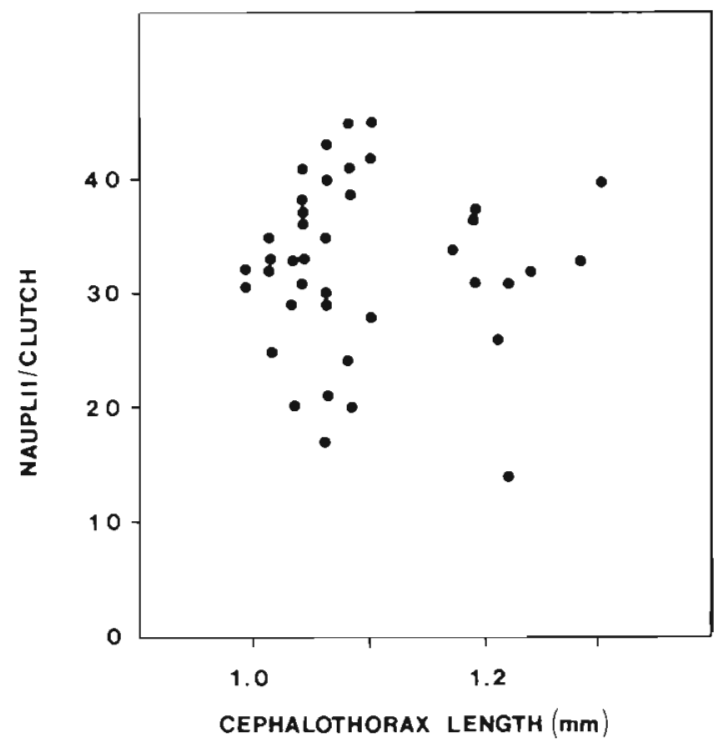

Fig. 3. Number of nauplii clutch $^{-1}$ produced by $P_{\text {seu- }}$ docalanus spp. females in shipboard experiments

equation of Corkett and McLaren (1978) predicts that Pseudocalanus spp. of the average size found in our study, $1.08 \pm .08 \mathrm{~mm}$ cephalothorax length, will produce 26.2 nauplii clutch $^{-1}$. The number of nauplii clutch $^{-1}$ for the small Oithona spp. females was not measured during our study, but is assumed to be the same as that measured for Oithona similis in an Arctic fiord, 16.2 nauplii clutch ${ }^{-1}$ (McLaren, 1969). This number closely corresponds with that found by Eaton 
(1971) for O. similis from Halifax Harbour, 16.7 eggs clutch $^{-1}$.

Hatching time of Pseudocalanus spp. eggs in our experiments at $6.5^{\circ} \mathrm{C}$ was always between 4.0 and $4.5 \mathrm{~d}(\overline{\mathrm{x}}=4.2, \mathrm{n}=48$ clutches). This was approximately equal to the $4.7 \mathrm{~d}$ predicted by the equation given by Corkett and McLaren (1970) for calculating hatching time of Pseudocalanus spp. as a function of temperature.

In our study, time between egg hatching and production of a new egg sac by Pseudocalanus spp. was always $<12 \mathrm{~h}$, the interval between observations. The brevity of this interval indicates the copepods were well nourished (Corkett and McLaren, 1978); the high concentrations of chlorophyll found throughout the water column (Fig. 4) further suggest food was abundant.

The close agreement between our Pseudocalanus spp. data and the equations derived from the more

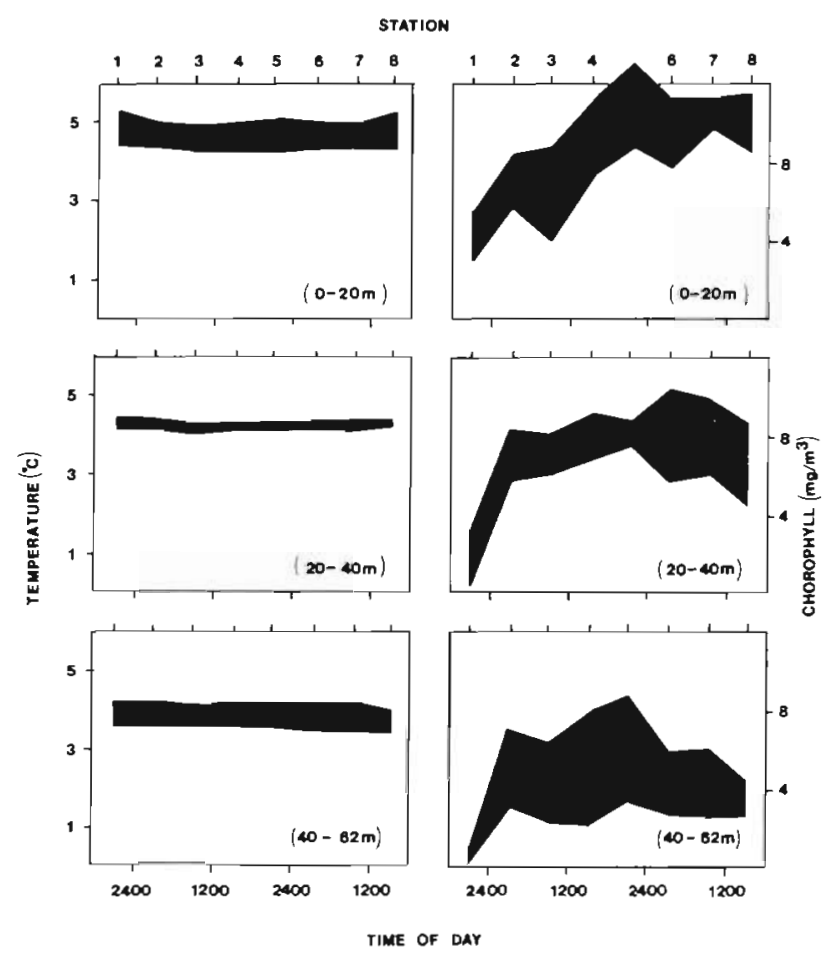

Fig. 4. Range of temperature and chlorophyll concentration in each depth stratum over $48 \mathrm{~h}$

extensive data of McLaren (1969, 1978), and Corkett and McLaren (1970), indicate that these equations can be applied with reasonable certainty to Pseudocalanus in our study area. We also believe that the equation derived by McLaren (1978) for Oithona similis can be applied to Oithona in our study area. These equations allow hatching times to be calculated at ambient temperatures, and also allow calculation of the time required for a newly hatched nauplius to develop to copepodid stage $I$.

It is necessary to know the temperature during egg development in order to calculate the in situ hatching time. For Pseudocalanus spp. this is taken to be $4.0^{\circ} \mathrm{C}$ (Fig. 4) because the majority of the adult females, which carry the eggs, were found in the deepest stratum (Fig. 2). For Oithona spp., most abundant in the upper stratum (Fig. 2), the temperature of egg development is taken to be $4.8^{\circ} \mathrm{C}$ (Fig. 4). The small temperature range in the water column (Fig. 4) indicates that hatching time would have been about the same at all depths during the period of this study, so the exact vertical location of the females is not crucial to our calculations.

The equation (Corkett and McLaren, 1970) for calculating the hatching of Pseudocalanus spp. eggs as a function of temperature (T) is

$$
\mathrm{D}=2,144\left(\mathrm{~T}^{\circ} \mathrm{C}+13.4\right)^{-2.05}
$$

At $4.0^{\circ} \mathrm{C}$ hatching time is $6.1 \mathrm{~d}$. Because the production of a new sac took $<0.5 \mathrm{~d}$, assume 0.4 , and each clutch produced an average of 33.0 nauplii, the average in situ production rate is 5.1 nauplii per Pseudocalanus spp. female $\mathrm{d}^{-1}$. Applying this rate to the abundance of females in each depth stratum, allows the total daily production of Pseudocalanus spp. nauplii to be calculated (Table 1). Average and standard deviation of the 8 estimates is $25,757 \pm 5,512$ Pseudocalanus spp. nauplii $\mathrm{m}^{-2} \mathrm{~d}^{-1}$.

For Oithona spp. the equation for calculating hatching time (McLaren, 1978) as a function of temperature is

$$
\mathrm{D}=1,430\left(\mathrm{~T}^{\circ} \mathrm{C}+5.0\right)^{-2.05}
$$

At $4.8{ }^{\circ} \mathrm{C}$ hatching time is $13.3 \mathrm{~d}$. If the production of a new egg sac takes $0.4 \mathrm{~d}$, and each clutch yields 16.2 nauplii, then the production rate is 1.2 nauplii per Oithona spp. female $\mathrm{d}^{-1}$. Applying this rate to the abundance of Oithona spp. females in each depth stratum, allows the total daily production of Oithona spp. nauplii to be calculated (Table 2). Average and standard deviation of the 8 estimates is $1,337 \pm 751$ Oithona spp. nauplii $\mathrm{m}^{-2} \mathrm{~d}^{-1}$.

The total daily production of nauplii by these 2 copepods averages $27,094 \pm 6,094 \mathrm{~m}^{-2}$, of which more than $95 \%$ are Pseudocalanus spp.

\section{Standing stock of copepod nauplii}

Direct measurements of the abundance and distribution of nauplii show that maximum concentrations were in the 15 to $20 \mathrm{~m}$ depth range and thus did not correspond with maximum concentrations of copepod females (Fig. 5). Whether the nauplii were released in 
Table 1. Daily production of Pseudocalanus spp. nauplii

\begin{tabular}{|c|c|c|c|c|c|}
\hline Station & $\begin{array}{l}\text { Depth } \\
\text { stratum } \\
\text { (In) }\end{array}$ & $\begin{array}{c}\text { Female } \\
\text { concentration } \\
\left(\text { no. } \mathrm{m}^{-3} \text { ) }\right.\end{array}$ & $\begin{array}{l}\text { Daily naupliar } \\
\text { production } \\
\text { (no. } \mathrm{m}^{-3} \text { ) }\end{array}$ & $\begin{array}{c}\text { Daily naupliar } \\
\text { production } \\
\text { (no. stratum }{ }^{-1} \text { ) }\end{array}$ & $\begin{array}{l}\text { Daily naupliar } \\
\text { production } \\
\left(\text { no. } \mathrm{m}^{-2} \text { ) }\right.\end{array}$ \\
\hline \multirow[t]{3}{*}{1} & $62-40$ & 258.8 & 1,314 & 28,908 & \\
\hline & $40-20$ & 34.2 & 174 & 3,480 & 36,108 \\
\hline & $20-0$ & 36.6 & 186 & 3,720 & \\
\hline \multirow[t]{3}{*}{2} & $62-40$ & 98.0 & 498 & 10,956 & \\
\hline & $40-20$ & 73.2 & 372 & 7,440 & 23,316 \\
\hline & $20-0$ & 48.4 & 246 & 4,920 & \\
\hline \multirow[t]{3}{*}{3} & $62-40$ & 164.0 & 833 & 18,326 & \\
\hline & $40-20$ & 37.4 & 190 & 3,800 & 29,686 \\
\hline & $20-0$ & 74.4 & 378 & 7,560 & \\
\hline \multirow[t]{3}{*}{4} & $62-40$ & 83.9 & 426 & 9,372 & \\
\hline & $40-20$ & 45.3 & 230 & 4,600 & 20,012 \\
\hline & $20-0$ & 59.5 & 302 & 6,040 & \\
\hline \multirow[t]{3}{*}{5} & $62-40$ & 126.4 & 642 & 14,124 & \\
\hline & $40-20$ & 24.1 & 122 & 2,440 & 21,824 \\
\hline & $20-0$ & 51.9 & 263 & 5,260 & \\
\hline \multirow[t]{3}{*}{6} & $62-40$ & 105.9 & 538 & 11,836 & \\
\hline & $40-20$ & 40.6 & 206 & 4,120 & 25,256 \\
\hline & $20-0$ & 81.8 & 415 & 9,300 & \\
\hline \multirow[t]{3}{*}{7} & $62-40$ & 116.4 & 591 & 13,002 & \\
\hline & $40-20$ & 9.9 & 50 & 1,000 & 20,802 \\
\hline & $20-0$ & 67.0 & 340 & 6,800 & \\
\hline \multirow[t]{3}{*}{8} & $62-40$ & 202.1 & 1,026 & 22,572 & \\
\hline & $40-20$ & 33.9 & 172 & 3,440 & 29,052 \\
\hline & $20-0$ & 30.0 & 52 & 3,040 & \\
\hline
\end{tabular}

Table 2. Daily production of Oithona spp. nauplii

\begin{tabular}{|c|c|c|c|c|c|}
\hline Station & $\begin{array}{l}\text { Depth } \\
\text { stratum } \\
\text { (m) }\end{array}$ & $\begin{array}{c}\text { Female } \\
\text { concentration } \\
\left(\text { no. } \mathrm{m}^{-3}\right)\end{array}$ & $\begin{array}{l}\text { Daily naupliar } \\
\text { production } \\
\left(\text { no. } \mathrm{m}^{-3} \text { ) }\right.\end{array}$ & $\begin{array}{c}\text { Daily naupliar } \\
\text { production } \\
(\text { no. stratum } \\
\text {-1) }\end{array}$ & $\begin{array}{l}\text { Daily naupliar } \\
\text { production } \\
\text { (no. } \mathrm{m}^{-2} \text { ) }\end{array}$ \\
\hline \multirow[t]{3}{*}{1} & $62-40$ & 24.9 & 29 & 647 & 2,921 \\
\hline & $40-20$ & 33.0 & 39 & 780 & \\
\hline & $20-0$ & 63.2 & 75 & 1.494 & \\
\hline \multirow[t]{3}{*}{2} & $62-40$ & 8.0 & 10 & 209 & \\
\hline & $40-20$ & 16.1 & 19 & 380 & 1,157 \\
\hline & $20-0$ & 24.0 & 28 & 568 & \\
\hline \multirow[t]{3}{*}{3} & $62-40$ & 6.9 & 8 & 180 & \\
\hline & $40-20$ & 10.2 & 12 & 242 & 728 \\
\hline & $20-0$ & 12.9 & 15 & 306 & \\
\hline \multirow[t]{3}{*}{4} & $62-40$ & 12.7 & 15 & 330 & \\
\hline & $40-20$ & 16.3 & 19 & 386 & 1,244 \\
\hline & $20-0$ & 22.3 & 26 & 528 & \\
\hline \multirow[t]{3}{*}{5} & $62-40$ & 3.4 & 4 & 88 & \\
\hline & $40-20$ & 12.2 & 14 & 288 & 844 \\
\hline & $20-0$ & 19.8 & 23 & 468 & \\
\hline \multirow[t]{3}{*}{6} & $62-40$ & 6.8 & 8 & 176 & \\
\hline & $40-20$ & 12.3 & 15 & 290 & 832 \\
\hline & $20-0$ & 19.7 & 23 & 466 & \\
\hline \multirow[t]{3}{*}{7} & $62-40$ & 11.4 & 14 & 297 & \\
\hline & $40-20$ & 9.7 & 12 & 230 & 887 \\
\hline & $20-0$ & 15.2 & 18 & 360 & \\
\hline \multirow[t]{3}{*}{8} & $62-40$ & 21.2 & 25 & 552 & \\
\hline & $40-20$ & 33.5 & 40 & 792 & 1,982 \\
\hline & $20-0$ & 27.0 & 32 & 638 & \\
\hline
\end{tabular}



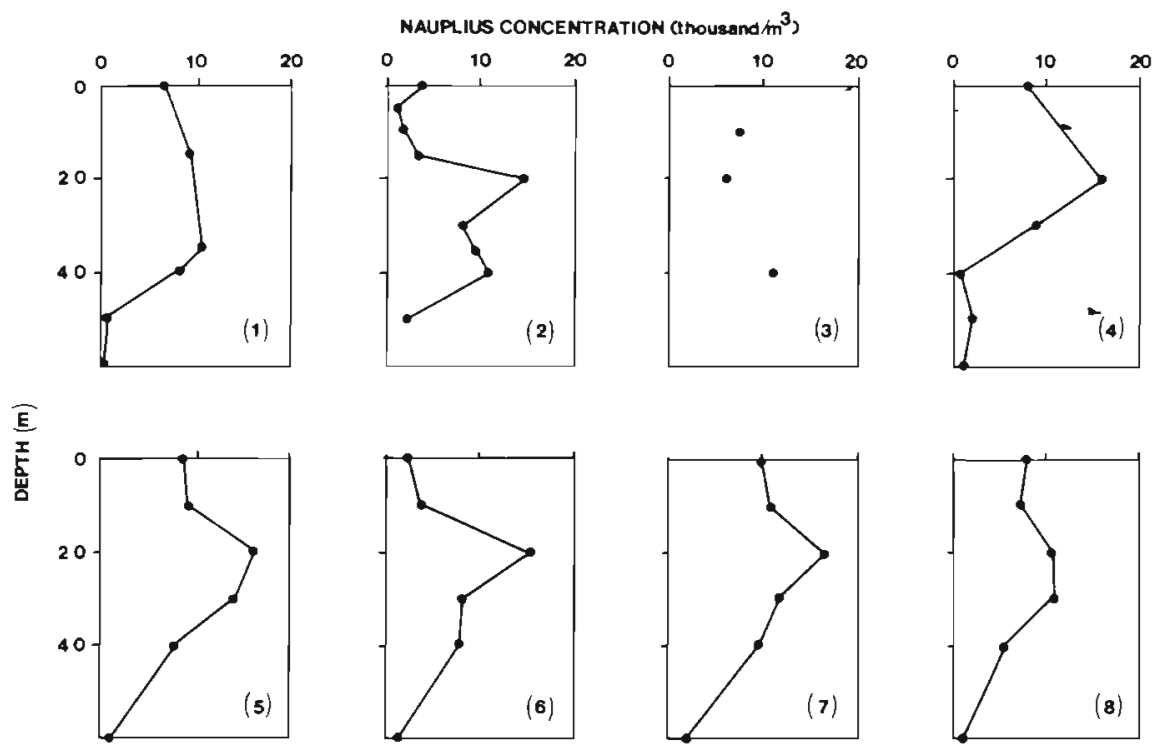

Fig. 5. Vertical distribution of copepod nauplii at each station over $48 \mathrm{~h}$ the 15 to $20 \mathrm{~m}$ depth range or they swam to these depths after hatching is not known. Below $40 \mathrm{~m}$, in the deepest stratum, nauplii were less abundant than anywhere else in the water column even though the abundance of copepod females was greatest in this stratum. Most of the nauplii in the water column were between 100 and $400 \mu \mathrm{m}$ long (Fig. 6).

The standing stock of nauplii in the water column, based on the 7 complete profiles shown in Fig. 5, averaged $463,173 \mathrm{~m}^{-2}$ (range $=337,870$ to 595,830 ). If these were homogenously distributed in the water column, the average concentration would be 7.5 nauplii $1^{-1}$ but the heterogeneous distribution results in maximum concentrations in the range of 15 to 20 nauplii $\mathrm{I}^{-1}$ at $20 \mathrm{~m}$.

Corkett and McLaren (1970) provide an equation for calculating the development time of Pseudocalanus from hatching to copepodid stage $I$, the total time spent in naupliar stages:

$$
\mathrm{D}=9,224\left(\mathrm{~T}^{\circ} \mathrm{C}+13.4\right)^{-2.05}
$$

At $4.5^{\circ} \mathrm{C}$, the average temperature at $20 \mathrm{~m}$ over this study period, this equation predicts that a newly hatched nauplius requires $24.9 \mathrm{~d}$ to develop to a copepodid. Thus each day's production of Pseudocalanus spp. nauplii would remain a part of the naupliar standing stock for $24.9 \mathrm{~d}$. Since 25,757 nauplii are produced $\mathrm{m}^{-2} \mathrm{~d}^{-1}$ by the observed stock of Pseudocalanus spp. females, the standing stock of nauplii would reach equilibrium at $641,349 \mathrm{~m}^{2}$ under the temperature regime observed during our study, assuming there is no naupliar mortality. However, corrections must be applied to this estimate for at least 2 reasons. Firstly, water temperatures had been increasing during the month prior to our study. At nearby stations surface temperatures increased by $1.5 \mathrm{C}^{\circ}$ and bottom temperatures by $0.2 \mathrm{C}^{\circ}$ during the period from May 2 to 25. Since the egg-carrying females were predominantly in bottom water, hatching time would not have changed appreciably, but the time required to develop to copepodid stage I would have been slightly longer during the month prior to our study. Cooler temperatures prior to our $48 \mathrm{~h}$ study result in an increase in our estimate of the stock of nauplii because the naupliar production from more than $24.9 \mathrm{~d}$ will contribute. Calculations indicate that the naupliar production from $28 \mathrm{~d}$ prior to our study would be present.

The second and most significant reason for a correction to our estimate of the potential stock of Pseudocalanus spp. nauplii is that the number of Pseudocalanus spp. females was probably not constant during the month prior to our study. Quantitative data from early May are not available for our stations but at a station approximately $100 \mathrm{~km}$ to the west, the number of Pseudocalanus spp. females increased from $3,360 \mathrm{~m}^{-2}$ to $7,295 \mathrm{~m}^{-2}$ over $23 \mathrm{~d}$, and at a station approximately $75 \mathrm{~km}$ to the northwest the number increased from $1,004 \mathrm{~m}^{-2}$ to $2,218 \mathrm{~m}^{-2}$ over the same period. Assuming that these increases were exponential, as observed over a similar period in 1980 (Smith and Vidal, 1984), results in instantaneous rates of increase equal to 0.0337 and $0.0345 \mathrm{~d}^{-1}$, for an average of $0.0341 \mathrm{~d}^{-1}$. Using this rate, the stock of Pseudocalanus spp. females present at our $48 \mathrm{~h}$ station during each of the previous $28 \mathrm{~d}$, and thus the naupliar production on each of these days, was calculated. The corrected estimate of the potential stock of Pseudocalanus spp. nauplii is $443,303 \mathrm{~m}^{-2}$, assuming no naupliar mortality.

For Oithona spp., the time required to develop from hatching to copepodid stage $\mathrm{I}$ is given by the equation:

$$
\mathrm{D}=6,023\left(\mathrm{~T}^{\circ} \mathrm{C}+5.0\right)^{-2.05}
$$


(McLaren, 1978). At $4.5^{\circ} \mathrm{C}$ this development time is $59.6 \mathrm{~d}$. Under the temperature conditions of our study, the 1,337 Oithona spp. nauplii produced daily would result in a standing stock of 79,685 Oithona spp. nauplii $\mathrm{m}^{-2}$, assuming no naupliar mortality. Application of corrections similar to those made for Pseudocalanus spp. are not as easily made for Oithona spp. because data on water temperature are not available for the entire $60 \mathrm{~d}$ prior to our study, and at nearby stations Oithona spp. females were not counted; only the combined abundances of copepodids, males and females are available. Nevertheless, by ignoring temperature corrections and assuming that the rate of change in Oithona spp. concentrations observed from May 2 to 25 at the nearby stations represents the rate of change in female concentrations that occurred over the prior $2 \mathrm{mo}$, a corrected estimate of potential stock of 52,025 Oithona spp. nauplii $\mathrm{m}^{-2}$ is obtained.

Thus our estimate of the stock of Pseudocalanus spp. and Oithona spp. nauplii that would be observed during our study period if there was no naupliar mortality during the prior 30 to $60 \mathrm{~d}$ is $495,328 \mathrm{~m}^{-2}$. This is only slightly greater than the average observed stock of nauplii of $463,173 \mathrm{~m}^{-2}$, suggesting that naupliar mortality from any source is low at this time.

\section{Predation rate of pollock larvae on copepod nauplii}

Pollock larvae of the yolk sac ( 3.5 to $5.0 \mathrm{~mm}$ ) and early post yolk sac (5.1 to $9.5 \mathrm{~mm}$ ) stages were highly concentrated in the 10 to $20 \mathrm{~m}$ depth stratum and virtually absent from the deep (60 to $40 \mathrm{~m}$ ) stratum (Fig. 7). Larval distribution was similar to naupliar distribution (Fig. 5 and 7). The size-frequency distribution of pollock larvae (Fig. 8 for sample station) shows that the larvae averaged $5.2 \mathrm{~mm}$ in length during our $48 \mathrm{~h}$ study. Ninety-five \% of the larvae that were captured had food in their guts, with an average of 6.1 food items per gut. Previous studies have shown that this is a reasonable level of gut fullness for larvae of this size. Clarke (1978) found 3 to 12 food items gut ${ }^{-1}$ for larvae in the 4.8 to $10.7 \mathrm{~mm}$ length range, and Takeuchi (1972) found an average of 5 food items gut $^{-1}$ for pollock in the 6.0 to $7.7 \mathrm{~mm}$ range. Analysis of the food remains in the guts of 238 larvae collected during our $48 \mathrm{~h}$ study showed that the prey items were mostly nauplii; of 1,445 prey items examined, 1,350 (93\%) were nauplii, $84(6 \%)$ were eggs, and $11(1 \%)$ were copepodids. Furthermore, the nauplii were mostly in the length range between 100 and $300 \mu \mathrm{m}$ (Fig. 9) and were therefore similar in size to the nauplii found in the water column (Fig. 6).

The number of nauplii per gut cannot be used to compute an ingestion rate unless information on the
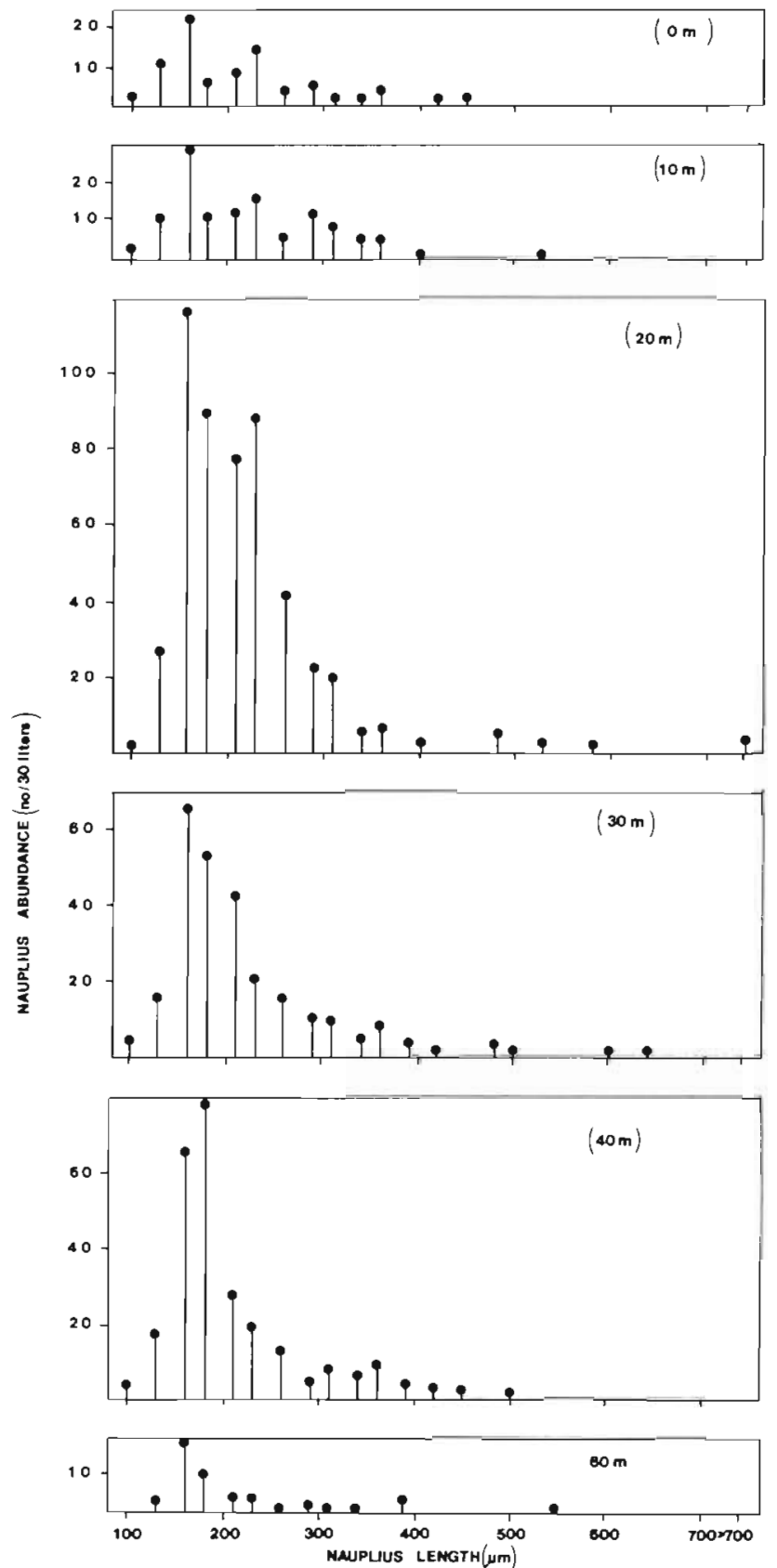

Fig. 6. Size-frequency distribution of copepod nauplii at a sample station (Station 6). Abundance as number per $30 \mathrm{l}$

digestion rate is available. Measurements of the gut clearance rate of 20 pollock larvae at $5.5^{\circ} \mathrm{C}$ showed that a mean of $5 \mathrm{~h}$ was required for larvae to void their guts of naupliar remains while feeding on Brachionus (Paul, 1983). In our study, each gut content is assumed to represent $5 \mathrm{~h}$ of feeding activity. Daylight length in late May is about $18 \mathrm{~h}$ but light levels at 10 to $30 \mathrm{~m}$ probably permit feeding for less than this duration, say $15 \mathrm{~h}$. Thus each larvae is estimated to ingest an average of 6.1 nauplii every $5 \mathrm{~h}$ during a $15 \mathrm{~h}$ period each day, or 18.3 nauplii $\mathrm{d}^{-1}$. Since the maximum abund- 


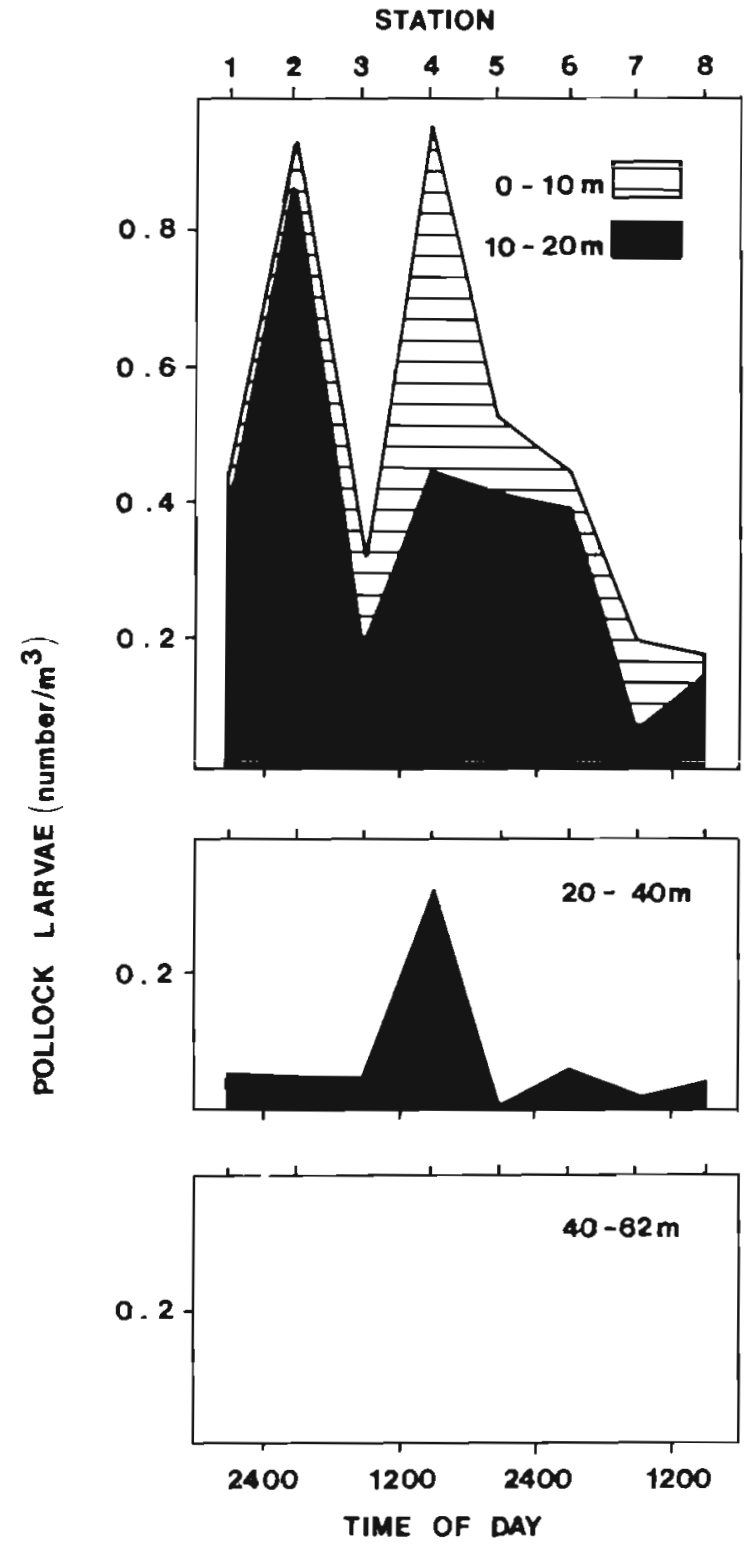

Fig. 7. Vertical distribution of pollock larvae $(3.5$ to $9.5 \mathrm{~mm}$ length) at each station over $48 \mathrm{~h}$

ance of pollock larvae observed during our study was $16 \mathrm{~m}^{-2}\left(\overline{\mathrm{x}}=6.3 \mathrm{~m}^{-2}\right)$, the predatory impact of pollock larvae on copepod nauplii is insignificant; of a daily naupliar production of $>27,000 \mathrm{~m}^{-2}$, the pollock larvae collectively ingest a maximum of $293 \mathrm{~m}^{-2}(\overline{\mathrm{x}}=$ $115 \mathrm{ml}^{-2}$ )

\section{DISCUSSION}

Although advection in the southeast Bering Sea does not cause the severe sampling problems that it does in many other areas (Coachman and Charnell, 1979), zooplankton populations are by no means homogenously distributed horizontally, and any estimates of popula- tion parameters must consider spatial variability. The consistency of our 8 replicate measurements of copepod abundance demonstrates that, by following a drogue, we minimized the importance of advective processes during our $48 \mathrm{~h}$ study. However, copepod abundances at 2 other stations within $100 \mathrm{~km}$ of our study area were quite different from each other and from our study area. Consequently, our calculation of the potential stock of nauplii must be treated with caution because it assumes that advection had not separated the females from the developing naupliar stages over the past 30 to $60 \mathrm{~d}$. Attempts to quantitatively estimate naupliar mortality by comparing the observed and predicted naupliar stocks are even more tenuous. Nevertheless, we believe that the similarity of the observed and predicted naupliar stocks indicates that overall naupliar mortality is low.

Examination of potential predators supports the sug-
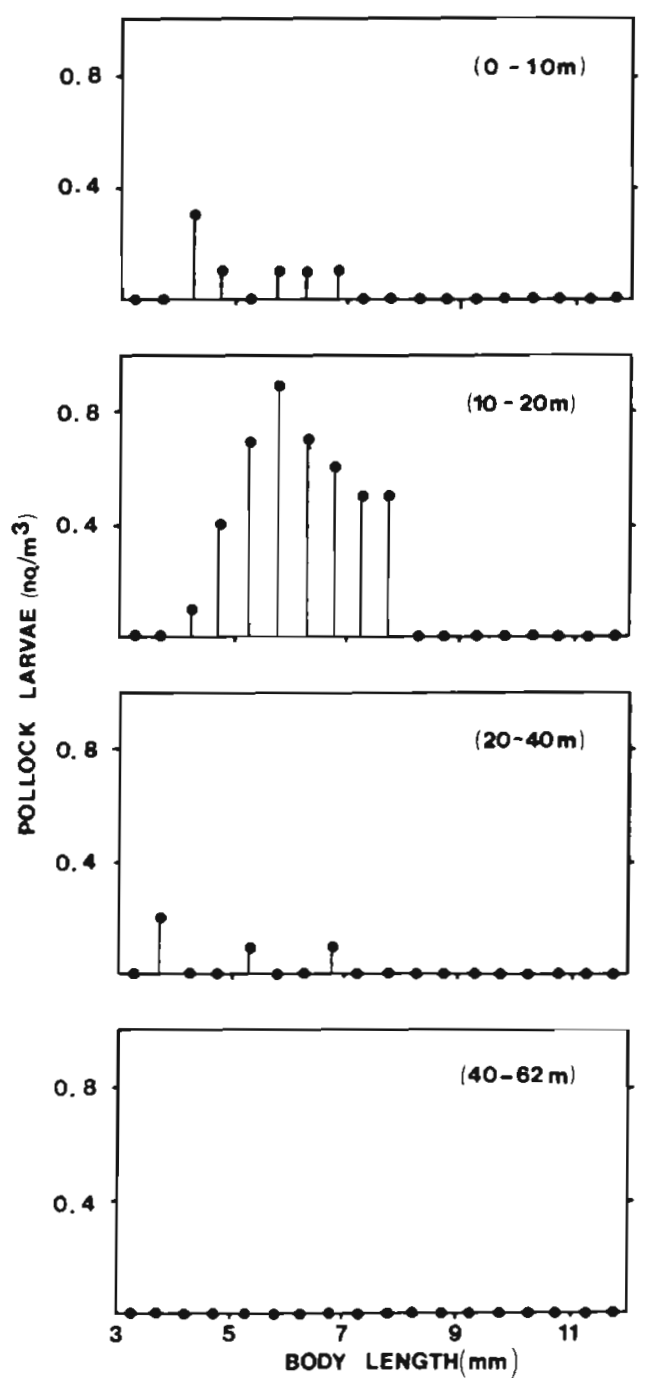

Fig. 8. Size-frequency distribution of pollock larvae at a sample station (Station 6). Abundance as number $m^{-3}$ 


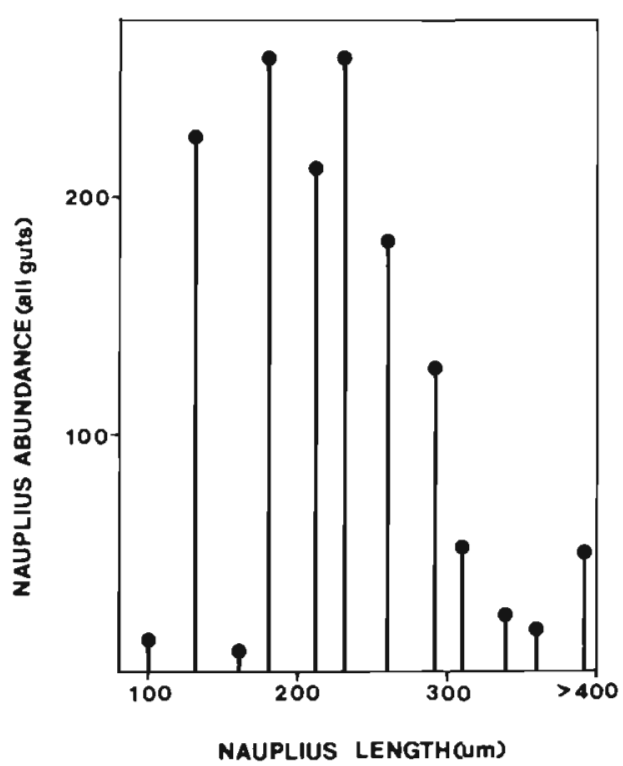

Fig. 9. Size-frequency distribution of nauplii from the guts of pollock larvae collected during our $48 \mathrm{~h}$ study

gestion that naupliar mortality is low. Pollock larvae ingested an average of only 115 nauplii $\mathrm{m}^{-2} \mathrm{~d}^{-1}$, a negligible fraction of the daily production of $27,094 \mathrm{~m}^{-2}$ by Pseudocalanus spp. and Oithona spp. Furthermore, since the spawning peak for pollock in this region is in early May, it is not likely that larval abundance will increase significantly after the time of our study, and this source of naupliar mortality is not likely to increase. Larvae of other fish species were much less abundant than pollock larvae and are not considered significant predators on nauplii. We concluded that during the spring phytoplankton bloom in this region, fish larvae have an insignificant impact on copepod population levels.

Other possible sources of naupliar mortality do not appear to be large. Invertebrate predators such as chaetognaths ( $\overline{\mathrm{X}}$ concentration of $124 \mathrm{~m}^{-2}$ ) and small $\left(<3 \mathrm{~mm}\right.$ ) medusae ( $\bar{X}$ concentration of $422 \mathrm{~m}^{-2}$ ) are sufficiently abundant to have some but not a major impact. If each ingested 3 nauplii $\mathrm{d}^{-1}, 1,638$ nauplii would be removed, equivalent to $6 \%$ of the daily production.

Oithona spp. is another potential predator on nauplii. Adults of the small Oithona nana are capable of feeding on nauplii of Acartia tonsa and Calanus finmarchicus (Lampitt, 1978; Lampitt and Gamble, 1982). If each Oithona spp. adult (average abundance of $1,131 \mathrm{~m}^{-2}$ ) and copepodid (average abundance of $2,000 \mathrm{~m}^{-2}$ ) in our study ingested 1 nauplius $\mathrm{d}^{-1}$, they would account for 3,131 nauplii $\mathrm{m}^{-2} \mathrm{~d}^{-1}$. Other predatory sources of naupliar mortality are not obvious.

Starvation as a source of naupliar mortality seems unlikely to be of major significance. Pseudocalanus spp. females, which produced $95 \%$ of the nauplii du- ring our study, were well fed and the high chlorophyll concentrations found throughout the water column suggest that nauplii would also be well fed. In an extensive review of Pseudocalanus spp. biology, Corkett and McLaren (1978) concluded that individuals of this genus were not food limited during the productive season, but grow at temperature-dependent rates, even in high latitudes.

Pseudocalanus and Oithona are widely distributed and abundant in northern seas and yet, because they carry egg sacs instead of freely releasing their eggs to the environment, they produce eggs at rates lower than most other copepods (Corkett and Zillioux, 1975). To attain high population levels these copepods must have relatively low mortality rates. We suggest that these 2 copepod genera are abundant because they minimize egg mortality by carrying egg sacs, and the nauplii develop during a period of low mortality from predators.

In conclusion, although comparison of observed and predicted stocks of copepod nauplii must be made cautiously, the similarity of both numbers suggests that overall naupliar mortality is low during the spring bloom. Mortality due to pollock and other fish larvae is insignificant, and generous estimates of mortality due to invertebrate predators can account for only about $18 \%$ of the daily naupliar production. The low mortality rate allows these 2 copepod genera to reach high population levels in spite of their relatively low reproductive rates.

Acknowledgements. We thank R, Iverson, D. Ninivaggi, J Vidal, K. Wyman, P. Lane, J. Dugas, E. Schwarting, J. Judson, B. Plonski, the captain and crew of the 'Thomas G. Thompson' for their valuable contributions to this study. This work is part of a multidisciplinary study titled 'Processes and Resources of the Bering Sea Shelf' or PROBES, and was supported by the Division of Polar Programs, National Science Foundation under Grant number DPP76-23340.

\section{LITERATURE CITED}

Clarke, M. E. (1978). Some aspects of feeding biology of larval walleye pollock, Theragra chalcogramma (Pallas) in the southeastern Bering Sea. M. S. thesis, University of Alaska

Coachman, L. K., Charnell, R. L. (1979). On lateral water mass interaction - a case study, Bristol Bay, Alaska. J. phys. Oceanogr. 9: 278-297

Corkett, C. J., McLaren, I. A. (1970). Relationships between development rate of eggs and older stages of copepods. J. mar. biol. Ass. U.K. 52: 161-168

Corkett, C. J., McLaren, I. A. (1978). This biology of Pseudocalanus. Adv. mar. Biol. 15: 1-231

Corkett, C. J., Zillioux, E. J. (1975). Studies on the effect of temperature on the egg laying of three species of calanoid copepods in the laboratory. Bull. Plankton Soc. Japan 21: $77-85$

Eaton, J. J. (1971). Studies on the feeding and reproductive 
biology of the marine cyclopoid copepod, Oithona similis, Claus. Ph. D. thesis, Dalhousie University

Hamai, I., Kyushin, K., Kinoshita, T. (1974). On the early larval growth, survival and variation of body form in the walleye pollock, Theragra chalcogramma (Pallas), in rearing experiment feeding the different diets. Bull. Fac. Fish. Hokkaido Univ. 25: 20-35

Hayashi, K., Kitahama, H., Suzuki, U., Endo, N. (1968). Suketodara yogyo-ki no seitai. - Donan taiheiyo 1964 nenkyugun no kotatsu (in Japan). J. Hokkaido Fish. Sci. Inst. 25: 394-403

Houde, E. D. (1978). Critical food concentrations for larvae of three species of subtropical marine fishes. Bull. mar. Sci. 28: 395-411

Kamba, M. (1977). Feeding habits and vertical distribution of walleye pollock, Theragra chalcogramma (Pallas) in early life history stage in Uchiura Bay, Hokkaido. Rep. Inst. North Pacif. Fish., Hokkaido Univ., Spec. Vol. 123-273

Lampitt, R. S. (1978). Carnivorous feeding by a small marine copepod. Limnol. Oceanogr. 23: 1228-1231

Lampitt, R. S., Gamble, J. D. (1982). Diet and respiration of the small planktonic marine copepod Oithona Rana. Mar. Biol. 66: 185-190

Lasker, R. (1975). Field criteria for survival of anchovy larvae: the relation between inshore chlorophyll maximum layers and successful first feeding. Fish. Bull. U.S. 73: 453-462

Lasker, R. (1978). The relation between oceanographic conditions and larval anchovy food in the California current: identification of factors contributing to recruitment failure. Rapp. P.-v. Réun. Cons. int. Explor. Mer 173: 212-230

Lasker, R., Feder, H. M., Theilacker, G. H., May, R. C. (1970) Feeding, growth, and survival of Engraulis mordax larvae reared in the laboratory. Mar. Biol. 5: 345-353

Laurence, G. C. (1974). Growth and survival of haddock Melanogrammus aeglefinus, larvae in relation to planktonic prey concentration. J. Fish. Res. Bd Can. 31 $1415-1419$

Laurence, G. C. (1977). A bioenergetic model for the analysis of feeding and survival potential of winter flounder Pseudopleuronectes americanus, larvae during the period from hatching to metamorphosis. Fish. Bull. U.S. 75 $529-546$

May, R. C. (1974). Larval mortality in marine fishes and the critical period concept. In: Blaxter, J. H. S. (ed.) The early life history of fish. Springer-Verlag, Heidelberg, p. 3-19

McLaren, I. A. (1969). Population and production ecology of zooplankton in Ogac Lake, a landlocked fjord on Baffin Island. J. Fish. Res. Bd Can. 26: 1485-1559

McLaren, I. A. (1978). Generation lengths of some temperate marine copepods: estimation, prediction, and implications. J. Fish. Res. Bd Can. 35: 1330-1342

Nishiyama, T., Hirano, K. (1984). Estimation of zooplankton weight in the gut of larval walleye pollock (Theragra chalcogramma). Bull. Plankton Soc. Japan (in press)

Paul, A. J. (1983). Light, temperature, nauplii concentrations, and prey capture by first feeding pollock larvae Theragra chalcogramma. Mar. Ecol. Prog. Ser. 13: 175-179

Saksena, V. P., Houde, E. D. (1972). Effect of food level on the growth and survival of laboratory-reared larvae of bay anchovy Anchoa mitchilli (Goode and Bean). J. exp. mar. Biol. Ecol. 8: 249-259

Smith, G. B. (1981). The biology of walleye pollock. In: Hood, D. H., Calder, J. A. (ed.) The eastern Bering Sea Shelf: oceanography and resources. University of Washington Press, Seattle, p. 527-551

Smith, S. L., Vidal, J. (1984). Spatial and temporal effects of salinity, temperature, and chlorophyll on the communities of zooplankton in the southeastern Bering Sea. J. mar. Res. 40: 221-257

Strickland, J. D., Parsons, T. R. (1968). A practical handbook of seawater analysis. Bull. Fish. Res. Bd Can. 167: 185-206

Takeuchi, I. (1972). Some observations of eggs and larvae of the Alaska pollock. Theragra chalcogramma (Pallas), off the west coast of Kamchatka. In: Takenouti, A. Y. (ed.) Biological oceanography of the northern North Pacific Ocean. Idemitsu Shoten, Japan, p. 613-620

Waldron, K. D. (1981). Ichthyoplankton. In: Hood, D. H. Calder, J. A. (ed.) The eastern Bering Sea Shelf: oceanography and resources. University of Washington Press, Seattle, p. 471-493

Walline, P. D. (1980). Growth of larval walleye pollock (Theragra chalcogramma) in the eastern Bering Sea, based on otolith increments of plankton-caught specimens from June-July, 1979. Northwest and Alaska Fisheries Center Processed Rept. 80-12: 1-27

Wiebe, P. H., Burt, K. H., Boyd, S. H., Morton, A. W. (1976). A multiple opening/closing net and environmental sensing system for sampling zooplankton. J. mar. Res. 34: 313-326 